\title{
Open Educational Product: Online Course Design for Internship Supervisors of an Undergraduate Course in the Health Area
}

\author{
Adriana Reis de Barros, Rozangela Maria de Almeida Fernandes Wyszomirska, \\ Kerle Dayana Tavares de Lucena \\ Universidade Estadual de Ciências da Saúde de Alagoas, Universidade Federal de Alagoas, Maceió, Brasil \\ Email: arbarros17@yahoo.com.br, rozangelaw@yahoo.com.br, kerledayana@gmail.com
}

How to cite this paper: de Barros, A. R., de Almeida Fernandes Wyszomirska, R. M., \& de Lucena, K. D. T. (2021). Open Educational Product: Online Course Design for Internship Supervisors of an Undergraduate Course in the Health Area. Creative Education, 12, 1397-1406.

https://doi.org/10.4236/ce.2021.126106

Received: May 17, 2021

Accepted: June 27, 2021

Published: June 30, 2021

Copyright (c) 2021 by author(s) and Scientific Research Publishing Inc. This work is licensed under the Creative Commons Attribution International License (CC BY 4.0).

http://creativecommons.org/licenses/by/4.0/

\begin{abstract}
The use of digital communication resources has provided practices and experiences in the field of education with virtual learning environments, thereby enabling greater participation and collaboration among those involved. The process of creating the course design emerged as an educational product performed in the Professional Master's Degree in Health and Technology Teaching at the State University of Health Sciences of Alagoas. Thus, the present article aimed to describe the design of an improvement course for pedagogical training in the online distance modality through the Moodle Platform for Occupational Therapy internship supervisors of a state public health institution, elaborated from a survey of pedagogical needs found as an object of study. For the development, the interactionist theory of education and the meaningful learning supported by Collaborative Online Learning were considered, serving as a basis for using a collaborative and reflective environment permeated by information technology in the development of less individualistic and more collaborative pedagogical and communicational practices in order to better reach learning objects and facilitate communication, thus promoting a necessary dialogue between the University and the practice scenarios in the service. We conclude that the design of the training course for internship supervisors was based on previous models and theories, such as Online Collaborative Learning (Harasim, 2015) and used active online methodologies, which provided an articulated and interactive knowledge and reflections on pedagogical needs in the teaching of in-service practices. Additionally, it is noteworthy that the use of the proposed model will be able to adapt to different pedagogical approaches and also be offered to other groups of participants.
\end{abstract}




\section{Keywords}

Educational Product, Collaborative Learning, Pedagogical Training

\section{Introduction}

Digital communication technologies are profoundly altering the dynamics of life in society (Araújo \& Vilaça, 2016), directly influencing daily activities, crossing several areas, such as communication, education and culture. With the advent of internet, conditions that allowed the emergence of educational resources and tools were created, providing advances in the creation, sharing and dissemination of human knowledge, including from textbooks and academic articles to classes and complete courses, in addition to software, videos, tools, materials or techniques that support learning and access to knowledge (Amante \& Quintas-Mendes, 2016).

Educational products, also known as technical-technological products, are valuable elements in the structure of professional master's degrees in Brazil and are characterized as pedagogical tools, developed by the professionals in training with organized knowledge aiming to make pedagogical practice feasible (Freire, Guerrine, \& Dutra, 2016).

According to Santos and Warren (2020), for health education, educational products can still play a pivotal role in the education-health interface, as it can assist health education actions with Family Health Units (FHU), hospitals, educational institutions, communities and any other intervention environment of these professionals.

In this context, based on previous results regarding the pedagogical needs of the internship supervisors of the Occupational Therapy course at the State University of Health Sciences of Alagoas, an educational product was developed, with a design of an online training for these supervisors. The participants of the course are health professionals who occupy a prominent role in academic discussions, as a professional who teaches in the work environments, which are potentially transformative scenarios in professional training (Ribeiro, Firmo, Sousa, Figueiredo, \& Pacheco, 2020).

For the development and construction of the course model, the interactionist theory of education, the meaningful learning and the integration between theory and practice were considered (Lima, 2017).

As an important theoretical basis for learning, the interactionist or social interactionist theory stands out, which allows knowledge through interaction with other people, in historical, cultural and social processes during the individual's life, allowing movements of social and cultural transformation (Oliveira et al., 2017). It is supported by Vygotsky's theory (2008), which uses previous knowledge of the participants as a starting point for the construction of new knowledge, postulating that development and learning are processes that influence 
each other with the interaction of the subject with the world (Lima, 2017).

Meaningful learning, a movement originated from the progressive education of Ausubel (1963), highlights the use of problems triggered in daily life and the possibility of finding a new sense and meaning (Moreira, 2012), when knowledge starts to make sense, using teaching as a process of communication and joint construction of knowledge (Sousa, Formiga, Oliveira, Costa, \& Soares, 2016; Santos, Alves, Warren, \& Wyszomirska, 2019).

Santaella (2003) reports the contemporary needs of teaching and learning, with reflection on the development of communication and technological innovations. The author presents a retrospective of the use of Information and Communication Technologies (ICTs) with the evolution of cultural formations and the communicational logics over time and describes by means of mobile devices the continuity of time that is added to the continuity of space.

Thereby, the use of digital communication resources has provided lessons and experiences with virtual learning environments, thus enabling greater participation and collaboration among those involved in the process as well as contributing to professional development (Paiva, 2010).

Conole \& Ehlers (2010) showed a learning model that articulates the major components for teaching, the possible relationships and interrelationships with a mapping of activities. The authors also demonstrated the importance of the interaction between different tools and techniques for e-learning literature, allowing flexibility and contextualization while being reflective and consistent.

In view of the proposal to create a learning space that allows contextualization and flexibility, Online Collaborative Learning (OCL) is identified as a theory that emphasizes the role of peer discourse as a key to learning, achieved through Generation of Ideas, Organization of Ideas and Intellectual Convergence, as progressive stages of group discourse (Harasim, 2015).

It is noteworthy that social interactivity through information technology enables the development of less individualistic and more collaborative pedagogical and communication practices. With the emergence of new concepts, such as virtual learning environments, virtual learning communities, distance education programs and online education, the construction of knowledge occurs in a contextualized way through digital technologies and resources to suppress physical distance and promote educational communication (Quintas-Mendes \& Wyszomirska, 2019).

In this sense, the creation of the course for online supervisors optimizes the time and space with work and studies of health professionals and the use of ICTs to enhance contemporary needs.

\section{Methodology}

The proposed course is offered with a workload of 40 hours, availability of 4 modules and a period of 30 days for completion of all modules.

The stages of the design of the construction of the offered course were:

- Bibliographic survey of theories of education: theoretical references of con- 
structivism, supported by the interactionist theory of education and meaningful learning.

- Elaboration of the learning objectives and the contents of the course, consistent with the pedagogical needs identified in the master's research previously performed.

- Elaboration of didactic sequence, with description of methodologies, activities and interactive resources used.

- Creation of a course design in the online distance modality, articulating the contents to the tools available through the digital platform.

The construction of the course design was based on Online Collaborative Learning (OCL), which was a theory proposed by Linda Harasim (2015), based on the environment and resources of the internet, promoting collaboration and knowledge construction with a focus on collaborative learning, and use of technological resources as a means of reshaping the formal, non-formal and informal for the Knowledge Age.

Furthermore, it complies with the regulations of the National Curriculum Guidelines and the Pedagogical Project of the Course, according to the principles of the Unified Health System, which establish professional training in the practice scenario (Brasil, 2002).

\section{Results and Discussion}

The course is centered on the model with interaction between the content offered and the interaction with digital resources to facilitate understanding, dialogue and, thus, the inclusion of participants. Applied to the tutorial instructions, the participant will be able to develop learning and to manage the knowledge process. The activities will be offered synchronously and asynchronously with the availability of videos, texts and podcasts through the Moodle Platform.

The design of the training course for internship supervisors is described in Figure 1, which shows, in the center, the Virtual Learning Environment (VLE) that helps teachers and tutors in content management and course administration, also allowing interactivity and monitoring of student progress.

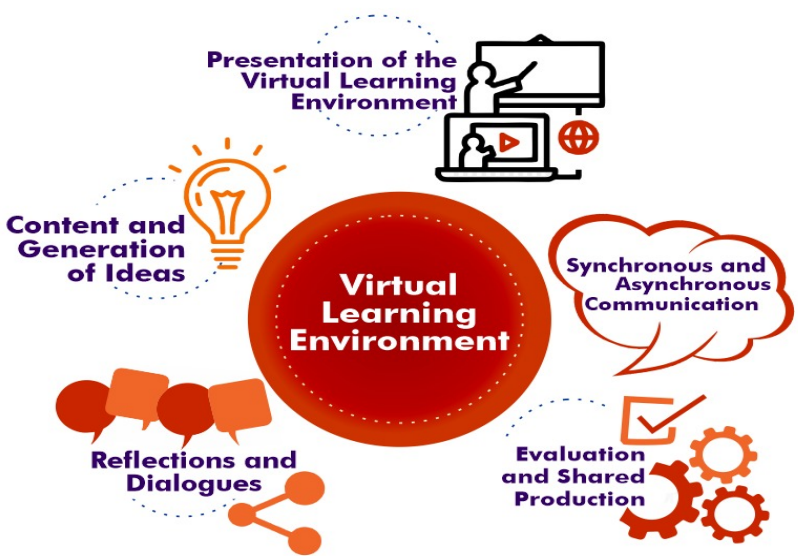

Figure 1. Design of the training course for internship supervisors. 
Regarding the Content and Generation of Ideas, the Pedagogical Project of the Course will be presented and important issues for the construction of internship plans as the final product of the course will be highlighted. Then, participants will be offered a brief presentation on experiences and practice scenarios and, as an activity, a report about the supervisor's role in the scenario of practices in the debate forum will be proposed as a brainstorm.

The item Reflections and Dialogues is characterized as a remarkable activity that allows the tutor to identify the knowledge and profile of each participant and helps to think critically about a question or topic for a possible adaptation or adequacy of the contents. Thus, it is possible to encourage the participation of all through the forums based on the availability of texts and videos, aiming at the exchange of knowledge and critical thinking.

Regarding the topic Synchronous and Asynchronous Communication, both forms of communication will be used, which will be arranged through the course schedule presented in the inaugural class.

Finally, the Evaluation and Shared Production should be highlighted, the stage of intellectual synthesis, during the seminar at the end of the course, with the presentation of the internship teaching plan as a product of the course in a shared and collaborative way.

Harasim (2015), in her course model, emphasized dialogue and debate as key factors for meaningful learning and knowledge construction. For the author, the teacher would be the learning facilitator through group discussion and the learners would be introduced in the language of the discipline, in order to understand the topic, apply the analytical terms in the speech and, thus, build knowledge. Further, Harasim (2015) also revealed the importance of three pivotal stages: creation and organization of ideas, besides to intellectual convergence. These elements are all represented in the model described in this study (generation of ideas, reflections and dialogues, shared production).

The course design for internship supervisors was also based on a study conducted by Garrison, Anderson and Archer (1999), in which the authors developed the Community of Inquiry model, based on the existence of three presences for meaningful learning: cognitive (construction of knowledge through reflections and speeches), social (interaction and an environment that allows interactivity) and teaching (course structure, with activities and resources).

The model presented here has the particularity of being directed at a specific group of learners, who are the internship supervisors, all with a higher degree and working as professionals in their area of training. Therefore, the social presence, with the structure of the course, was carefully elaborated, observing the special characteristics of this group.

Thus, the Didactic Sequence (Frame 1) starts with a remote meeting, followed by a forum to know and identify the professional experience of each one. Finally, the course will appropriate the use of active online methodologies in each module. 
Frame 1. Didactic Sequence of the training course for internship supervisors.

\section{Module 1}

Initially, the participants of the course will be welcomed into the Virtual Learning Environment (VLE), followed by the presentation of the responsible professional, the teaching plan and schedule of activities

Opening of the FORUM strategy for general presentation of the participants: training time, continuing education, tutoring time and supervision

Provision of texts and articles for reading through the PASTA resource about internship regulation documents, duties of the mandatory internship supervisor and the Practices as a Curricular Component to encourage discussions in the FORUM activity.

Provision of a link to access the download of an open educational resource through the URL: Preceptorship in Health: A Possible Partnership.

Use of the CHAT strategy for sharing opinions and insights about the material as the closing of the module.

Module 2

The Problem-Based Learning (PBL) strategy will be used in distance learning modality. Based on constructivist theories, the student is encouraged to be part of the process of building learning through challenging situations. The activity promotes group work and stimulates individual, student-centered study.

Opening of FORUM activities to promote dialogue between participants on the development of potential and teaching skills and competences based on the experiences and challenges of internships in the service.

\section{$1^{\text {st }}$ moment}

Theme: DCNs and the importance for internships-Reading of Resolution CNE/CES No. 6, OF 19 of February of 2002. Clarification of terms that are difficult to understand;

List the points related to professional skills and competences in the internship practices identified in the DCN;

Opening of a web conference room in two moments to apply the PBL methodology, following the script: Individual search for information on the subject, with recommended use of books, texts and articles, expert opinions, searches in databases, such as MEDLINE, LILACS and others.

$2^{\text {nd }}$ moment

Return to the tutorial meeting with exchange of information and closing of the topic, with presentation of the summary using the graphical tool (conceptual or mental map).

Module 3

The online "Team-Based Learning" (TBL) methodology will be used, through the Moodle Platform.

Theme: To know the main pedagogical theories and active methodologies, for the development of the pedagogical and didactic activities of the internship.

One week before the virtual meeting: availability of material (texts, videos) to guarantee reading using PASTA and URL resources on the main learning theories.

Opening of a web conference room (Big Blue Button or Google Meet) for the step-by-step of the TBL script

- Opening of activity using QUESTIONNAIRE strategy of the Moodle Platform or through a form, with 10 questions on the main learning theories and active methodologies, to promote the individual preparation of students.

- After completing the questionnaire, opening of parallel classrooms, in proportion to the number of students, each room with a maximum of five to seven participants, for group discussion about the questions of the individual questionnaire.

- Next, opening of activity, after the end of the discussions, using QUESTIONNAIRE strategy again, with 10 questions about the main learning theories and active methodologies, to promote the group preparation of the participants, who must respond with the consensus of the students.

Return to the virtual classroom, using the technological tool Big Blue Button or Google Meet to present the results of the questionnaires, answer questions and to receive feedback from the teacher.

Module 4

Project Based Learning will be used with a powerful pedagogical approach to meet the demands of current society.

It will be experienced in two stages:

Theme: Design of Online Learning and Use of Information and Communication Technologies in Education, applied to supervised internships. 


\section{Continued}

$1^{\text {st }}$ Stage:

-Use of the FORUM strategy for the presentation of the guiding question and the triggering of the investigative process and studies on the proposed theme, for later presentation and debate.

-Availability of material (texts, videos) for reading using PASTA and URL resources

-Construction of a teaching plan for internship.

$2^{\text {nd }}$ Stage:

Under the guidance of the responsible teacher, the participants must prepare a mandatory supervised internship teaching plan project, through theoretical research for application in practice, and develop the product.

Final Evaluation:

Opening of a web conference room (Big Blue Bottom or Google Meet), to present the Internship Plan as a product of the training course and completion of the course.

The final evaluation will be formative and summative, according to participation and fulfillment of activities and tasks throughout the course.

Evaluation and Validation of the Course:

Opening of activity using QUESTIONNAIRE strategy, for evaluation and validation of the course by the students, with feedback from the teacher after the end.

Problem-Based Learning was used to discuss the theme of the National Curriculum Guidelines for the Occupational Therapy course, with two sessions, on different days, in online format, following the method adopted by the University of Maastricht, Netherlands (Wood, 2003). The discussions during the first analysis session (brainstorming) were rich, with the creation of a summary, a conceptual map and the identification of learning objectives for the individual study and organization of ideas. With the continuation of the discussion in the second session, of resolution, the intellectual convergence and synthesis of the discussion were carried out.

The online Team-Based Learning (TBL) was used to promote the discussion on the main pedagogical theories, in module 3. For this, the step-by-step described for the methodology in the online format was followed (Wyszomirska et al., 2021), which brought significant learning according to the participants, by adding theoretical knowledge on education to the exercise of practical supervision.

For module 4, Project-Based Learning was used, culminating with the presentation of a product for the completion of the course. The methodology emphasizes activities performed through projects, whose focus is the collective construction of knowledge in which students are the protagonists and learn in cooperation with their peers (Larmer \& Mergendoller, 2010).

With the development of the modules, the participants exercised communication, with good interaction between peers and professors. It is believed that the course allowed, in an articulated way, to present the necessary knowledge to respond to the students' demands regarding pedagogical practices.

\section{Conclusion}

The design of the training course for internship supervisors was based on previous models and theories, such as Online Collaborative Learning (Harasim, 2015), 
in addition to using active online methodologies.

From this study, the importance of creating and applying a course design can be seen by mapping the needs of the participants in order to build and enhance the learning objectives with didactic approaches and the choice of interactive tools for the construction and improvement of knowledge, with emphasis on the exercise of communication and interaction between the participants.

The use and adaptation of the proposed model can adapt to different pedagogical approaches and still be offered to other participants, in search of individualized and/or collective needs. Notwithstanding that, it is necessary to expand the adaptive potential of the course modeling and to understand the limitations of the proposed design.

The applicability of the educational product with the use of communication information technologies to create a reflective and creative learning environment is able to stimulate professional development and, thus, facilitate communication and promote a necessary dialogue between the University and the practice scenarios in the service.

Finally, we suggest carrying out more research using active online methodologies, as a reflective and creative learning environment for teaching in health and professional development.

\section{Conflicts of Interest}

The authors declare no conflicts of interest regarding the publication of this paper.

\section{References}

Amante, L., \& Quintas-Mendes, A. (2016). Distance Education, Open Education and Inclusion of Models Transmissive to Open Practices. Inclusao Social, 10, 49-65. http://revista.ibict.br/inclusao/issue/view/242

Araújo, E. V. F., \& Vilaça, M. L. C. (2016). Sociedade Conectada: Tecnologia, Cidadania e Infoinclusão. In M. L. C. Vilaça, \& E. V. F. Araújo (Org) (Eds.), Tecnologia, Sociedade e Educação na Era Digital (pp. 17-40). Duque de Caxias: Unigranrio. http://www.pgcl.uenf.br/arquivos/tecnologia,sociedadeeeducacaonaeradigital 0111201 81554.pdf

Ausubel, D. P. (1963). The Psychology of Meaningful Verbal Learning. New York, NY: Grune and Stratton.

Brasil (2002). Conselho Nacional de Educação., Câmara de Educação Superior. In editor, Resolução No. CNE/CES 6, de 19 de fevereiro. Institui Diretrizes Curriculares Nacionais do Curso de Graduação em Terapia Ocupacional. http://portal.mec.gov.br/cne/arquivos/pdf/CES062002.pdf

Conole, G., \& Ehlers, U. D. (2010). Open Educational Practices: Unleashing the Power of OER. Paper Presented to UNESCO Workshop on OER in Namibia (pp. 1-10). Windhoek. https://www.oerknowledgecloud.org/archive/OEP Unleashing-the-power-of-OER.pdf

Freire, G. G., Guerrini, D., \& Dutra, A. (2016). O Mestrado Profissional em Ensino e os Produtos Educacionais: A Pesquisa na Formação Docente. Porto Das Letras, 2, 100-114. https://sistemas.uft.edu.br/periodicos/index.php/portodasletras/article/view/2658 
Harasim, L. (2015). Educação Online e as Implicações da Inteligência Artificial. Educação e Contemporaneidade, 24, 25-39.

https://revistas.uneb.br/index.php/faeeba/article/view/1818/1232

Garrison, D. R., Anderson, T., \& Archer, W. (1999). Critical Inquiry in a Text-Based Environment: Computer Conferencing in Higher Education. The Internet and Higher Education, 2, 87-105. https://doi.org/10.1016/S1096-7516(00)00016-6

Larmer, J., \& Mergendoller, J. R. (2010). Seven Essentials for Project-Based Learning. Educational Leadership, 68, 34-37.

http://www.ascd.org/publications/educational leadership/sept10/vol68/num01/Seven Essentials for Project-Based Learning.aspx

Lima, V. V. (2017). Abordagem Educacional Construtivista. In M. S. Oliveira, et al. (Eds.), Preceptoria no SUS: Caderno do Curso, Hospital Sírio-Libanês (pp. 13-19). São Paulo: Ministério da Saúde.

Moreira, M. A. (2012). ¿Al afinal, qué es aprendizaje siginificativo? Revista Curriculum, 25, 29-56.

https://lume.ufrgs.br/bitstream/handle/10183/96956/000900432.pdf?sequence=1\&isAll owed $=y$

Oliveira, M. S., Lima, V. V., Petta, H. L., Pereira, S. M. S. F., Ribeiro, E. C. O., \& Padilha, R. Q. (2017). Preceptoria no SUS: Caderno do Curso. Projeto Apoio ao SUS. São Paulo, Sírio Libanês. São Paulo: Ministério da Saúde.

Paiva, V. M. de O. (2010). Ambientes Virtuais de Aprendizagem: Implicações Epistemo lógicas. Educação em Revista, 26, 353-370. https://doi.org/10.1590/S0102-46982010000300018

Quintas-Mendes, A. M., \& Wyszomirska, R. M. de A. F. (2019). Educação e Formação Docente no Contexto da Educação a Distância Online. Revista Tempos e Espaço em Educação, 11, 93-112. https://doi.org/10.20952/revtee.v11i01.9895.

Ribeiro, P. K. C., Firmo, W. C. A., Sousa, M. H. S. L., Figueiredo, I. A., \& Pacheco, M. A. B. (2020). Os Profissionais de Saúde e a Prática de Preceptoria na Atenção Básica: Assistência, Formação e Transformações Possíveis. Journal of Management and Primary Health Care, 12, 1-18. https://doi.org/10.14295/jmphc.v12.977

Santaella, L. (2003). Da Cultura das Mídias à Cibercultura: O Advento do Pós-Humano. Revista FAMECOS, 10, 23-32. https://doi.org/10.15448/1980-3729.2003.22.3229 https://revistaseletronicas.pucrs.br/ojs/index.php/revistafamecos/article/view/3229

Santos, A. A., Alves, C. F., Warren, E. M. C., \& Wyszomirska, R. M. de A. F. (2019). Integrated Model of Course Based on Edu-Communication and Psycho-Communication in Learning. Creative Education, 10, 1080-1090. https://doi.org/10.4236/ce.2019.106081

Santos, A. A., \& Warren, E. M. C. (2020). Método CTM3 Como Dispositivo de Ensino, Aprendizagem e Comunicação em Produtos Educacionais. In: A. A. Santos (Ed.), Educação em Saúde: Trabalhando com Produtos Educacionais (pp. 13-30), Maceió: Editora Hawking. https://doi.org/10.29327/522658

Sousa, A. T. O., Formiga, N. S., Oliveira, S. H. S., Costa, M. M. L., \& Soares, M. J. G. O. (2016). A Utilização da Teoria da Aprendizagem Significativa no Ensino da Enfermagem. Revista Brasileira de Enfermagem, 68, 713-722. https://doi.org/10.1590/0034-7167.2015680420i

Vygotsky, L. S. (2008). Pensamento e Linguagem. 4a. Edição, São Paulo: Martins Fontes.

Wood, D. F. (2003). Problem Based Learning. BMJ, 326, 328-330.

https://doi.org/10.1136/bmj.326.7384.328

Wyszomirska, R. M. A. F., Pennaforte, R., de Barros Costa, F., Warren, E., \& Quintas- 
A. R. de Barros et al.

Mendes, A. (2021). Team-Based Learning: A Promising Strategy for Use in Online. Creative Education, 12, 278-292.

https://www.scirp.org/journal/paperinformation.aspx?paperid $=106958$ 